Bull. Chem. Soc. Ethiop. 2016, 30(2), 209-220.

Printed in Ethiopia

DOI: http://dx.doi.org/10.4314/bcse.v30i2.5

ISSN 1011-3924

(c) 2016 Chemical Society of Ethiopia

\title{
SYNTHESIS, PHYSICAL CHARACTERIZATION, ANTIBACTERIAL ACTIVITY AND THERMODYNAMIC STUDIES OF FIVE COODRDINATE COBALT(III) SCHIFF BASE COMPLEXES
}

\author{
Sheida Esmaielzadeh", Zohreh Zare and Leila Azimian \\ Department of Chemistry, Darab Branch, Islamic Azad University, Darab, Iran
}

(Received April 12, 2015; revised June 19, 2016)

\begin{abstract}
Some five-coordinated cobalt(III) complexes were synthesized and characterized using elemental analysis, ${ }^{1} \mathrm{H}$ NMR and IR spectra. The formation constants and the thermodynamic parameters were measured spectrophotometrically for the $1: 1$ adduct formation of $\left[\mathrm{Co}(\mathrm{Chel})\left(\mathrm{PBu}_{3}\right)\right] \mathrm{ClO}_{4} \cdot \mathrm{H}_{2} \mathrm{O}$ where $\mathrm{Chel}=$ cd $3 \mathrm{OMesalen}$, cd4OMesalen, cd5OMesalen: methyl-2-\{[1-methyl-2-(2-hydroxy-3-, 4-, 5-methoxyphenyl)methylidynenitrilo]ethyl \}amino-1-cyclopentene-dithiocarboxylate, as acceptors, with some linear and cyclic amines as donors, in different solvents at constant ionic strength $\left(\mathrm{I}=0.1 \mathrm{M} \mathrm{NaClO}_{4}\right)$, and at various temperatures $(\mathrm{T}=283-313 \mathrm{~K})$. The results revealed that the formation constants of the Co(III) Schiff base complexes toward a given amines donor are as follow: $\left[\mathrm{Co}(\mathrm{cd} 4 \mathrm{OM} \text { esalMeen })\left(\mathrm{PBu}_{3}\right)\right]^{+}>\left[\mathrm{Co}(\mathrm{cd} 3 \mathrm{OMesalMeen})\left(\mathrm{PBu}_{3}\right)\right]^{+}>$ $\left[\mathrm{Co}(\mathrm{cd} 5 \mathrm{OM} \text { esalMeen })\left(\mathrm{PBu}_{3}\right)\right]^{+}$. The trend of the formation constants of the donors (amines) toward a given cobalt(III) complex is as follow: Im $>4$-MeIm $>$ BzIm and n-butylamine $>$ sec-butylamine $>$ tert-butylamine. Also the effect of the solvents on the formation constants of a given cobalt(III) Schiff base complex toward a given donor are as follow: $\mathrm{CH}_{3} \mathrm{CN}>\mathrm{DMF}>\mathrm{EtOH}$. The ligands and their cobalt complexes have been screened for their antibacterial activities. All the free Schiff base ligands exhibit higher antibacterial activity than the cobalt(III) complexes.
\end{abstract}

KEY WORDS: Cobalt (III) Schiff base complex, Thermodynamic parameters, Amines, Antibacterial activity

\section{INTRODUCTION}

For a long time tetradentate Schiff base complexes of transition metal ions have attracted many researchers interest in the field of coordination chemistry [1-4]. Though a large number of papers have appeared on metal complexes with Schiff base derived from aromatic aldehydes and substituted amines with $\mathrm{N}_{4}$ and $\mathrm{N}_{2} \mathrm{O}_{2}$ coordination sphere [5-8], only few publications exist on Schiff bases containing sulfur donor ligands. These groups of Schiff base ligands are subject of current interest. They arise in part because of their varied structures and because of their biological activities, vital role in medicine, industries, agricultural applications, coordination chemistry and many more [9-11]. The field of medicine has witnessed an increase in the number of complexes with therapeutic value, for example copper(II) Schiff base complex is as anticancer agent [12], Mn(II), Co(II), Zn(II) Schiff base complexes have antibacterial and cytotoxic activities [13], cobalt(III) Schiff base complexes are potential antiviral and antitumor agents [14]. The coordination chemistry of cobalt is of considerable interest since cobalt(II) and cobalt(III) complexes derived Schiff base are reported to be biologically active. Vitamin $\mathrm{B}_{12}$, which is involved in the production of red blood cells, is a cobalt(III) complex with a substituted corrin macrocycle. Cobalt(III) complexes have shown specific hypoxic radiosensitization, photosensitization and thermosensitization as well as antibacterial, antifungal and antitumor activity in vivo [15-17]. Several cobalt(III) complexes coordinated through the Schiff base donors have been studied as oxygen carrier and they are useful models for bioinorganic processes, and also as catalysts for water-splitting systems [18].

In order to mimic such living systems and to shed some light on binding modes and to continue our investigation in the field of Schiff base complexes with NNOS coordination sphere

*Corresponding author. E-mail: esmaielzadehsheida@yahoo.com 
[19-23], we report here the synthesis, characterization and spectral studies of the new complexes $\left[\mathrm{Co}(\mathrm{Chel})\left(\mathrm{PBu}_{3}\right)\right] \mathrm{ClO}_{4} \cdot \mathrm{H}_{2} \mathrm{O}$ where Chel $=$ cd3OMesalMeen, cd4OMesalMeen, cd5OMesalMeen: Methyl-2-\{[1-methyl-2-(2-hydroxy-3-, 4-, 5-methoxy-phenyl) methylidynenitrilo] ethyl $\}$ amino-1-cyclopentenedithiocarboxylate. The solid products are well characterized by elemental analyses, UV-Vis, NMR spectra, along with the assignment of their infrared spectra for most of the fundamental vibrations. In addition, this paper describes thermodynamic studies of five coordinated cobalt(III) complexes in equilibrium with amines as the sixth ligand in ethanol, $\mathrm{CH}_{3} \mathrm{CN}$ and DMF as solvents. Using these results, the effects of the electronic and the steric properties of the ligands on the formation constants of complexes were also discussed.

\section{EXPERIMENTAL}

\section{Reagents and physical measurements}

All chemicals and solvents were purchased from Merck and Fluka and were used without further purification. Amines were purified by drying with $\mathrm{KOH}$ and $\mathrm{CaH}_{2}$ then distilled. The solvents were purchased from commercial sources and were analytical grade.

Electronic absorption spectra were carried out in a Perkin Elmer (LAMBDA 2) UV-Vis spectrophotometer equipped with a LAUDA ecoline RE 104 thermostat. The NMR spectra were recorded by Bruker Avance DPX $400 \mathrm{MHz}$ spectrometer. IR spectra were recorded by Shimadzu FTIR 8300 infrared spectrophotometer. Elemental analysis was carried out by Termo Fininngan-Flash 1200.

\section{Synthesis and characterization of complexes}

The Schiff base ligands, $\mathrm{H}_{2} \mathrm{~cd} 3 \mathrm{OMesalMeen}, \mathrm{H}_{2} \mathrm{~cd} 4 \mathrm{OMesalMeen}, \mathrm{H}_{2}$ cd5OMesalMeen, were prepared according to procedures described in the literature [20, 24-26]. The complexes shown in Scheme 1 were synthesized as follow: To a refluxing solution of the unsymmetrical ligands $\left(\mathrm{H}_{2} \mathrm{~cd} 3-, 4-, 5-O M e s a l M e e n\right)(0.1 \mathrm{mmol})$ in $10 \mathrm{~mL}$ of chloroform/methanol mixture (2:1) under $\mathrm{N}_{2}$ atmosphere, was added a solution of $\mathrm{Co}\left(\mathrm{CH}_{3} \mathrm{COO}\right)_{2} \cdot 4 \mathrm{H}_{2} \mathrm{O}(1 \mathrm{mmol})$ in methanol $(10 \mathrm{~mL})$ drop wisely. The deep brown or red solution of $\mathrm{Co}^{(\mathrm{II})}(\mathrm{L})$ complexes were precipitated, then the tributylphosphine $(0.1 \mathrm{mmol})$ was added and the reaction mixture was refluxed for 5-6 hours. The formed $\mathrm{Co}$ (II) complex was oxidized by blowing air into the solution for 2 hours, and the solution was filtered. An appropriate amount of sodium perchlorate $(0.1 \mathrm{mmol})$ was added to the filtrate. The resulting green crystals were formed after staying for $48 \mathrm{~h}$ and were removed by filtration and washed with portions of distilled water and methanol and purified by recrystallization from water-methanol mixture $(2: 1 \mathrm{v} / \mathrm{v})$, and finally dried in vacuum at $30{ }^{\circ} \mathrm{C}$ for $48 \mathrm{~h}$.

Caution. Although no difficulties were experiences, cobalt(III) complexes were isolated as their perchlorates, and therefore, they should be handled as potentially explosive compounds.

\{Methyl-2-[1-methyl[2-(3-methoxy-2-phenolate)ethylidynenitrilo]ethyl\}aminato(-1)-1cyclopentenedithiocarboxylatetribu\}tylphosphinecobalt(III) perchlorate monohydrate, [Co(cd3OMesalMeen) $\left.\left(\mathrm{PBu}_{3}\right)\right] \mathrm{ClO}_{4} \cdot \mathrm{H}_{2} \mathrm{O}$. Yield: 56\%; m.p.: $301{ }^{\circ} \mathrm{C} ;{ }^{1} \mathrm{H}$ NMR $(400 \mathrm{MHz}$, DMSO-d $_{6}$, r.t., TMS, $\delta$ ppm): $0.85(3 \mathrm{H}, \mathrm{d}, \mathrm{Me}), 1.28-1.62\left(9 \mathrm{H}, \mathrm{t}, \mathrm{P}-\mathrm{CH}_{3}\right), 1.94-2.03(18 \mathrm{H}, \mathrm{m}, \mathrm{P}-$ $\left.\left(\mathrm{CH}_{2}\right)_{3}\right), 2.54\left(2 \mathrm{H}, \mathrm{m}, \mathrm{H}^{4}\right), 2.96(3 \mathrm{H}, \mathrm{s}, \mathrm{SMe}), 3.04-3.20\left(4 \mathrm{H}, \mathrm{m}, \mathrm{H}^{3^{\prime}, 5^{\prime}}\right), 3.65\left(2 \mathrm{H}, \mathrm{d}, \mathrm{H}^{\mathrm{en}}\right), 3.86$ $(3 \mathrm{H}, \mathrm{s}, \mathrm{OMe}), 4.42\left(1 \mathrm{H}, \mathrm{m}, \mathrm{H}^{\mathrm{en}}\right), 6.74\left(1 \mathrm{H}, \mathrm{dd}, \mathrm{H}^{4}\right), 6.80\left(1 \mathrm{H}, \mathrm{d}, \mathrm{H}^{5}\right), 6.91\left(1 \mathrm{H}, \mathrm{d}, \mathrm{H}^{6}\right), 8.56(1 \mathrm{H}$, $\mathrm{s}, \mathrm{CH}=\mathrm{N})$; IR $\left(\mathrm{KBr}, \mathrm{cm}^{-1}\right): 456\left(v_{\mathrm{Co}-\mathrm{N}}\right), 579\left(v_{\mathrm{Co}-\mathrm{O}}\right), 737\left(v_{\mathrm{C}-\mathrm{S}}\right), 1094\left(v_{\mathrm{ClO} 4}\right), 1180\left(v_{\mathrm{C}-\mathrm{S}+} v_{\mathrm{C}-\mathrm{N}}\right), 1246$ $\left(v_{\mathrm{C}-\mathrm{O}}\right), 1444\left(v_{\mathrm{C}=\mathrm{C}}\right.$ aromatic $), 1607,1614\left(v_{\mathrm{C}=\mathrm{N}}\right), 2930\left(v_{\mathrm{C}-\mathrm{H}}\right), 3420\left(v_{\mathrm{O}-\mathrm{H}}\right)$; UV-Vis (DMF) $\left(\lambda_{\max } /\right.$ 
nm): 468, 698; Anal. calcd for: $\mathrm{C}_{30} \mathrm{H}_{52} \mathrm{~N}_{2} \mathrm{ClO}_{7} \mathrm{CoS}_{2} \mathrm{P}: \mathrm{C}, 48.55, \mathrm{H}, 7.06, \mathrm{~N}, 3.77, \mathrm{~S}$, 8.64. Found: C, 48.43, H, 6.94, N, 4.02, S, 8.73\%.

\{Methyl-2-[1-methyl[2-(4-methoxy-2-phenolate)ethylidynenitrilo] ethyl\}aminato(-1)-1cyclopentenedithiocarboxylatetribu;tylphosphinecobalt(III) perchlorate monohydrate, [Co(cd4OMesalMeen) $\left.\left(\mathrm{PBu}_{3}\right)\right] \mathrm{ClO}_{4} \cdot \mathrm{H}_{2} \mathrm{O}$. Yield: 48\%; m.p.: $316{ }^{\circ} \mathrm{C} ;{ }^{1} \mathrm{H}$ NMR $(400 \mathrm{MHz}$, DMSO-d 6 , r.t., TMS, $\delta$ ppm): $0.86(3 \mathrm{H}, \mathrm{d}, \mathrm{Me}), 1.31-1.55\left(9 \mathrm{H}, \mathrm{t}, \mathrm{P}-\mathrm{CH}_{3}\right), 1.98-2.12(18 \mathrm{H}, \mathrm{m}, \mathrm{P}-$ $\left.\left(\mathrm{CH}_{2}\right)_{3}\right), 2.46\left(2 \mathrm{H}, \mathrm{m}, \mathrm{H}^{4}\right), 2.95(3 \mathrm{H}, \mathrm{s}, \mathrm{SMe}), 3.02-3.50\left(4 \mathrm{H}, \mathrm{m}, \mathrm{H}^{3^{\prime} 5^{\prime}}\right), 3.56\left(2 \mathrm{H}, \mathrm{d}, \mathrm{H}^{\mathrm{en}}\right), 3.82$ $(3 \mathrm{H}, \mathrm{s}, \mathrm{OMe}), 4.44\left(1 \mathrm{H}, \mathrm{m}, \mathrm{H}^{\mathrm{en}}\right), 6.45\left(1 \mathrm{H}, \mathrm{d}, \mathrm{H}^{5}\right), 6.62\left(1 \mathrm{H}, \mathrm{s}, \mathrm{H}^{3}\right), 7.31\left(1 \mathrm{H}, \mathrm{d}, \mathrm{H}^{6}\right), 8.40(1 \mathrm{H}, \mathrm{s}$, $\mathrm{CH}=\mathrm{N})$; IR $\left(\mathrm{KBr}, \mathrm{cm}^{-1}\right): 432\left(v_{\mathrm{Co}-\mathrm{N}}\right), 583\left(v_{\mathrm{Co}-\mathrm{O}}\right), 723\left(v_{\mathrm{C}-\mathrm{S}}\right), 1094\left(v_{\mathrm{ClO} 4}\right), 1156\left(v_{\mathrm{C}-\mathrm{S}+} v_{\mathrm{C}-\mathrm{N}}\right)$, 1226 $\left(v_{\mathrm{C}-\mathrm{O}}\right), 1441\left(v_{\mathrm{C}=\mathrm{C}}\right.$ aromatic), 1600, $1607\left(v_{\mathrm{C}=\mathrm{N}}\right), 2958\left(v_{\mathrm{C}-\mathrm{H}}\right), 3434\left(v_{\mathrm{O}-\mathrm{H}}\right)$; UV-Vis (DMF) $\left(\lambda_{\max } / \mathrm{nm}\right)$ : 460, 696; Anal. calcd. for: $\mathrm{C}_{30} \mathrm{H}_{52} \mathrm{~N}_{2} \mathrm{ClO}_{7} \mathrm{CoS}_{2} \mathrm{P}: \mathrm{C}, 48.55, \mathrm{H}, 7.06, \mathrm{~N}, 3.77, \mathrm{~S}, 8.64$. Found: C, 48.55, H, 7.12, N, 3.96, S, 8.82\%.

\{Methyl-2-[1-methyl[2-(5-methoxy-2-phenolate)ethylidynenitrilo]ethyl\}aminato(-1)-1cyclopentenedithiocarboxylatetribu\}tylphosphinecobalt(III) perchlorate monohydrate, [Co(cd5OMesalMeen) $\left.\left(\mathrm{PBu}_{3}\right)\right] \mathrm{ClO}_{4} \cdot \mathrm{H}_{2} \mathrm{O}$. Yield: 54\%; m.p.: $209{ }^{\circ} \mathrm{C} ;{ }^{1} \mathrm{H}$ NMR $(250 \mathrm{MHz}$, DMSO-d $_{6}$, r.t., TMS, $\delta$ ppm): $0.84(3 \mathrm{H}, \mathrm{d}, \mathrm{Me}), 1.27-1.55\left(9 \mathrm{H}, \mathrm{t}, \mathrm{P}-\mathrm{CH}_{3}\right), 1.96-2.14(18 \mathrm{H}, \mathrm{m}, \mathrm{P}-$ $\left.\left(\mathrm{CH}_{2}\right)_{3}\right), 2.44\left(2 \mathrm{H}, \mathrm{m}, \mathrm{H}^{4}\right), 3.10(3 \mathrm{H}, \mathrm{s}, \mathrm{SMe}), 2.74-3.40\left(4 \mathrm{H}, \mathrm{m}, \mathrm{H}^{3^{\prime} 5^{\prime}}\right), 3.35\left(2 \mathrm{H}, \mathrm{d}, \mathrm{H}^{\mathrm{en}}\right), 3.50$ $(3 \mathrm{H}, \mathrm{s}, \mathrm{OMe}), 3.92\left(1 \mathrm{H}, \mathrm{m}, \mathrm{H}^{\mathrm{en}}\right), 6.51\left(1 \mathrm{H}, \mathrm{s}, \mathrm{H}^{6}\right), 6.60\left(1 \mathrm{H}, \mathrm{d}, \mathrm{H}^{4}\right), 6.67\left(1 \mathrm{H}, \mathrm{d}, \mathrm{H}^{3}\right), 8.33(1 \mathrm{H}, \mathrm{s}$, $\mathrm{CH}=\mathrm{N}) ; \mathrm{IR}\left(\mathrm{KBr}, \mathrm{cm}^{-1}\right): 424\left(v_{\mathrm{Co}-\mathrm{N}}\right), 555\left(v_{\mathrm{Co}-\mathrm{O}}\right), 724\left(v_{\mathrm{C}-\mathrm{S}}\right), 1095\left(v_{\mathrm{ClO} 4}\right), 1111\left(v_{\mathrm{C}-\mathrm{S}+} v_{\mathrm{C}-\mathrm{N}}\right), 1225$ $\left(v_{\mathrm{C}-\mathrm{O}}\right), 1446\left(v_{\mathrm{C}=\mathrm{C}}\right.$ aromatic), 1615, $1631\left(v_{\mathrm{C}=\mathrm{N}}\right), 2958\left(v_{\mathrm{C}-\mathrm{H}}\right), 3424\left(v_{\mathrm{O}-\mathrm{H}}\right)$; UV-Vis $(\mathrm{DMF})\left(\lambda_{\max } /\right.$ $\mathrm{nm})$ : 456, 700; Anal. calcd. for: $\mathrm{C}_{30} \mathrm{H}_{52} \mathrm{~N}_{2} \mathrm{ClO}_{7} \mathrm{CoS}_{2} \mathrm{P}: \mathrm{C}, 48.55$, H, 7.06, N, 3.77, S, 8.64. Found: C, 48.34, H, 7.32, N, 3.64, S, 8.58\%.

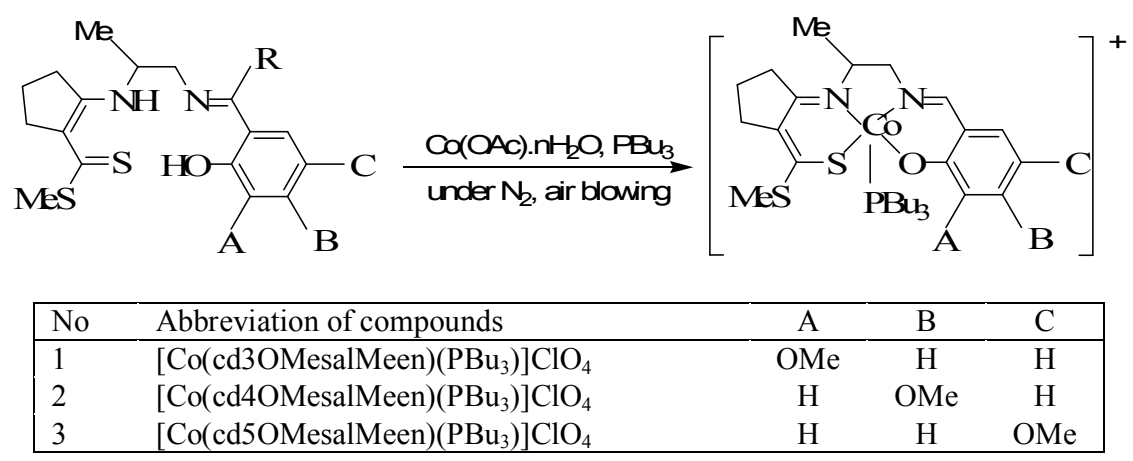

Scheme 1

Thermodynamic studies

The adducts were obtained from the reaction of the acceptors with the donors, according to Eq. (1).

$\left[\mathrm{Co}(\mathrm{Chel})\left(\mathrm{PBu}_{3}\right)\right]^{+}+$Amine $\leftrightarrow\left[\mathrm{Co}(\mathrm{Chel})\left(\mathrm{PBu}_{3}\right)(\text { amine })\right]^{+}$

where Chel $=$ cd3OMesalMeen, cd4OMesalMeen, cd5OMesalMeen, and amine $=$ cyclic amines (Im, 4-MeIm, BzIm), aliphatic amines ( $n$-butylamine, sec-butylamine, tert-butylamine). A solution from each complex $\left(10^{-5}-10^{-4} \mathrm{M}\right)$ with a constant ionic strength $(\mathrm{I}=0.1 \mathrm{M})$ by adding sodium perchlorate was prepared. In a typical titration, $2.5 \mathrm{~mL}$ of this solution was transferred 
into the thermostated cell compartment of the UV-Vis instrument, which was kept at constant temperature $\left( \pm 1{ }^{\circ} \mathrm{C}\right)$ by circulating water and was titrated by the amines. The titration was performed by adding aliquots of the amine with a Hamilton microlitre syringe. The donor concentrations were varied in the range of one-to-ten fold in excess.

The absorption measurements were carried out at various wavelengths in $380-450 \mathrm{~nm}$ regions where the difference in absorption between the substrate and the product was the largest after the equilibrium was assessed. The formed adduct shows an absorption different from the acceptor, while the donors show no absorption at those wavelengths. As an example, the variation of the electronic spectra for $\left[\mathrm{Co}(\mathrm{cd} 4 \mathrm{OMesalMeen})\left(\mathrm{PBu}_{3}\right)\right] \mathrm{ClO}_{4} \cdot \mathrm{H}_{2} \mathrm{O}$ titrated with $\mathrm{Im}$ at $\mathrm{T}=283 \mathrm{~K}$ in DMF is shown in Figure 1. The isosbestic points for this system show that there is only one reaction in equilibrium. The same are valid for the other systems.

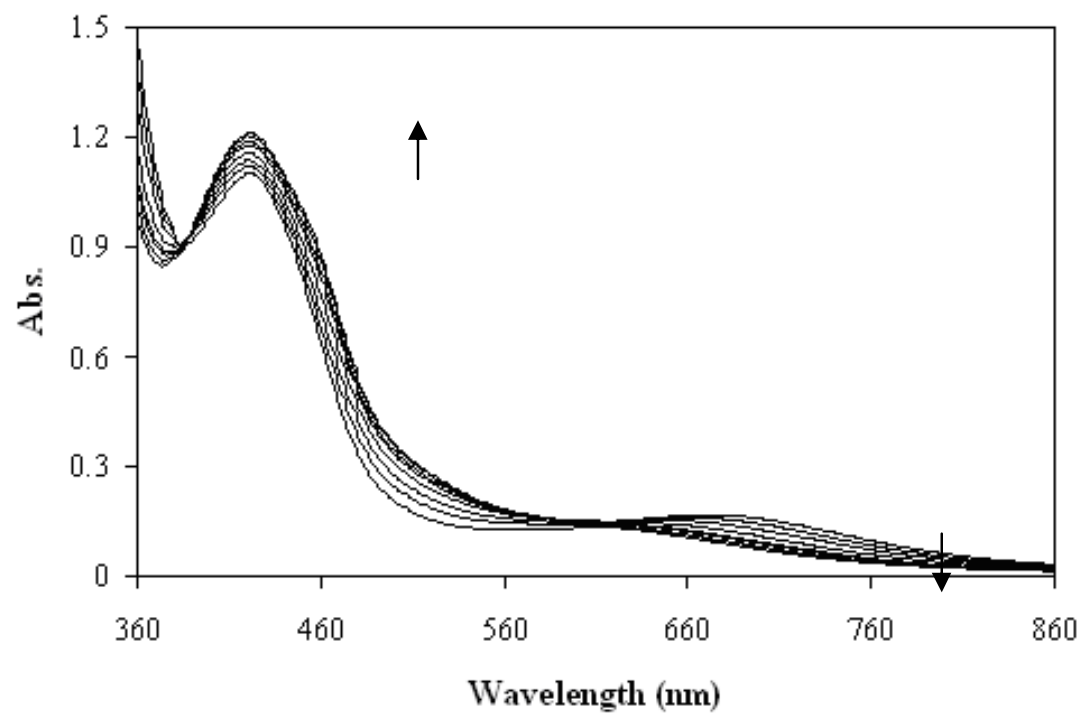

Figure 1. The variation of the electronic spectra for $\left[\mathrm{Co}(\mathrm{cd} 4 \mathrm{OMesalMeen})\left(\mathrm{PBu}_{3}\right)\right] \mathrm{ClO}_{4} \cdot \mathrm{H}_{2} \mathrm{O}$ titrated with Im at $293 \mathrm{~K}$ in DMF.

\section{RESULTS AND DISCUSSION}

IR spectra and mode of bonding

All complexes show similar IR spectral features exhibiting a broad absorption peaks for $v(\mathrm{O}-\mathrm{H})$ appear in the range $3420-3434 \mathrm{~cm}^{-1}$, respectively, indicating the presence of lattice water molecules [27]. The weak bands at $2920-2970 \mathrm{~cm}^{-1}$ in the ligands are related to $\mathrm{C}-\mathrm{H}$ modes of vibrations. In cobalt(III) complexes containing $\mathrm{PBu}_{3}$ these bands were very stronger, as assignable to $\mathrm{C}-\mathrm{H}$ vibrations of $\mathrm{PBu}_{3}$ [22]. The strong absorption band between $1600-1634 \mathrm{~cm}^{-1}$ corresponding to azomethine $(\mathrm{C}=\mathrm{N})$ groups, this band is shifted to lower frequencies by 4-22 $\mathrm{cm}^{-1}$ relative to the free ligand upon the coordination of the nitrogen atoms [28]. The band observed in the region of $1441-1446 \mathrm{~cm}^{-1}$ is ascribed to the $(\mathrm{C}=\mathrm{C})$ ring skeletal vibrations [18]. The sharp intensity bands around $1200 \mathrm{~cm}^{-1}$ region are assigned to $v(\mathrm{C}-\mathrm{O})$ band stretching vibration [29]. The band due to the $v(\mathrm{C}-\mathrm{S})+v(\mathrm{C}-\mathrm{N})$ vibration mode in complexes have the maximum in the region $1111-1180 \mathrm{~cm}^{-1}$ [19]. The FT-IR spectrum of the complexes exhibits a 
strong band of the perchlorate stretching vibrations, which are typical of non-coordinating perchlorate [30]. The $v(\mathrm{C}-\mathrm{S})$ stretching frequency occurred at $723-737 \mathrm{~cm}^{-1}$ [31]. New bands which are not present in the spectra of free Schiff bases appeared in the range 555-583 and 424$456 \mathrm{~cm}^{-1}$ are attributed to $v(\mathrm{Co}-\mathrm{O})$ and $v(\mathrm{Co}-\mathrm{N})$ vibration, respectively [32]. The appearance of the vibration supports the involvement of the nitrogen and oxygen atoms of the azomethine and $\mathrm{CO}$ group complexation with the Co(III) ion under investigations $[18,28]$.

\section{$U V$-Vis spectral studies}

The electronic absorption spectra are often very helpful in the evaluation of results provided by other methods of structural investigation. The study of the electronic spectra in the ultraviolet and visible ranges for ligands and their cobalt (III) complexes were carried out in ethanol $95 \%$. The ligands exhibit the band at 312-316 nm and 393-398 nm regions. The band at 312-316 nm can be assigned to intraligand $\pi \rightarrow \pi^{*}$ transition, the band almost unchanged in spectra of all the $\mathrm{Co}(\mathrm{III})$ complexes. The band at $393-398 \mathrm{~nm}$ on low energy side is due to $\mathrm{n} \rightarrow \pi^{*}$ transition associated with the azomethine linkage $[18,20]$. After complexation with $\mathrm{Co}(\mathrm{III})$ an intense $\mathrm{d} \rightarrow \pi^{*}$ charge transfer band appears in the $650-750 \mathrm{~nm}$ region in non-coordinating solvents that indicate the five coordinate structure for all the adduct reaction studied. The $\mathrm{d} \rightarrow \pi^{*}$ charge transfer depended on the charge density in the Schiff base. In the thermodynamic studies of the five-coordinated complexes with amines and formation of six-coordinated complexes this band shifts to lower energy because of the increasing charge density over the metal ion and the $\mathrm{d} \rightarrow \pi^{*}$ charge transfer was easier, so a new absorption band at 450-470 $\mathrm{nm}$ region (shoulder, $\mathrm{d} \rightarrow \pi^{*}$ ) appeared and the absorption band at 650-750 nm vanished [33] (see Figure 1). The isosbestic point shows that there is one equilibrium system in the adduct formation.

\section{${ }^{I} H$ NMR spectra}

The coordinating modes of the ligands were confirmed by comparing ${ }^{1} \mathrm{H}$ NMR spectra of the ligands and their complexes which were recorded in $\mathrm{d}_{6}$-DMSO using TMS as an internal standard. The NMR spectral data of diamagnetic $\mathrm{Co}$ (III) complexes and the chemical shifts of the different types of protons were presented in experimental section. The spectra of the complexes are examined in comparison with those of the parent Schiff bases [20]. Upon examination it was found that the $-\mathrm{OH}$ and $-\mathrm{NH}$ signals that appeared in the spectra of the ligands in the region 12.45-13.53 and 12.37-12.38 ppm completely disappeared in the spectra of their $\mathrm{Co}(\mathrm{III})$ complexes, indicating that the $\mathrm{OH}$ and $\mathrm{NH}$ protons are removed by chelation with the $\mathrm{Co}(\mathrm{III})$ ion $[34,35]$. The singlet signals in the region $8.33-8.56 \mathrm{ppm}$ have been assigned to two equivalent imine protons $(-\mathrm{CCH}=\mathrm{N})$ [36]. The aromatic protons of the phenyl rings were observed in complex pattern in the range of 6.45-7.31 ppm [37]. A singlet peak at 3.50-3.86 ppm with three proton integration has been assigned to the methyl moiety of the methoxy group [38]. Methyl protons on the diamine bridge and SMe group show singlet signals at $0.84-0.86$ and 2.95-3.10 ppm. The multiplet signals appearing at 1.27-2.14 ppm, respectively, corresponds to $\mathrm{PBu}_{3}$ group [22].

\section{Thermodynamic interpretations}

The formation constants of the various cobalt(III) unsymmetrical Schiff base complexes with the donors studied were calculated by using Ketelaar's Equation (2) [39].

$$
P=\frac{1}{\left(\varepsilon_{C}-\varepsilon_{A}-\varepsilon_{D}\right)} \cdot\left[\frac{1}{K}+\left(C_{A}^{\circ}+C_{D}^{\circ}\right)\right]
$$


where $P=C_{A}^{\circ} \times C_{D}^{\circ} /\left(A-A_{A}^{\circ}-A_{D}^{\circ}\right), \mathrm{C}_{\mathrm{A}}^{\circ}$ and $C_{D}^{\circ}$ are the initial concentrations (mol. $\left.\mathrm{dm}^{-3}\right)$ of the acceptor and the donor, respectively. $A$ is the optical density of the solution including the acceptor and the donor, $A_{A}^{\circ}$ and $A_{D}^{\circ}$ are the optical densities of the pure acceptor and the pure donor in the solution of concentrations $C_{A}^{\circ}$ and $C_{D}^{\circ}, \varepsilon_{C}, \varepsilon_{A}$ and $\varepsilon_{D}$ are the molar extinction coefficients $\left(\mathrm{mol}^{-1} \mathrm{dm}^{3} \mathrm{~cm}^{-1}\right)$ of the complex, the acceptor and the donor, respectively. $K$ is the formation constant of the formed adduct and the cell optical path length is $1 \mathrm{~cm}$.

The linear plots of $P$ against $\left(C_{A}^{\circ}+C_{D}^{\circ}\right)$ should produce a straight line if only a $1: 1$, and would lead to a curve if a 1:2 or a mixture of $1: 1$ and 1:2 complexes are present in a system. The formation constants of the studied cobalt(III) Schiff base complexes were calculated from the ratio of the slope to the intercept by least square method using computer software. The linear plot for [Co(cd4OMesalMeen) $\left.\left(\mathrm{PBu}_{3}\right)\right] \mathrm{ClO}_{4} \cdot \mathrm{H}_{2} \mathrm{O}$ titrated with $\mathrm{Im}$ at $293 \mathrm{~K}$ in DMF is shown in Figure 2 which signify that only a 1:1 adduct is formed. Similar plots are obtained for the other systems.

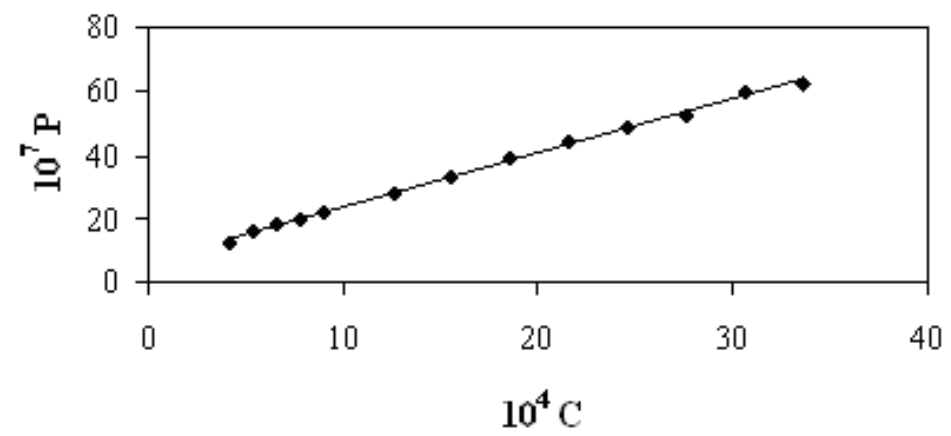

Figure 2. The typical plots of $\mathrm{P}$ vs. $\mathrm{C}$ for $\left[\mathrm{Co}(\mathrm{cd} 4 \mathrm{OMesalMeen})\left(\mathrm{PBu}_{3}\right)\right] \mathrm{ClO}_{4} \cdot \mathrm{H}_{2} \mathrm{O}$ with $\mathrm{Im}$ at $293 \mathrm{~K}$ in DMF, $\mathrm{I}=0.1 \mathrm{M}\left(\mathrm{NaClO}_{4}\right) \cdot \mathbf{P}=\left(\mathbf{C}_{\mathrm{A}}^{\circ} \times \mathbf{C}_{\mathbf{D}}^{\circ}\right) /\left(\mathbf{A}-\mathbf{A}_{\mathbf{A}}^{\circ}-\mathbf{A}_{\mathbf{D}}^{\circ}\right), \mathrm{C}=\left(C_{A}^{\circ}+C_{D}^{\circ}\right)$

The thermodynamic parameters of the studied cobalt(III) unsymmetrical Schiff base complexes were calculated by using of the well-known van't Hoff Equation (3):

$\ln K=\frac{-\Delta H^{\circ}}{R T}+\frac{\Delta S^{\circ}}{R}$

where $K$ is the formation constant, $R$ is the gas constant and $T$ is the temperature in Kelvin. Thermodynamic parameters of the studied complexes were obtained from the linear plots of $\ln K$ against $1 / T$. The values of $\Delta H^{\circ}$ and $\Delta S^{\circ}$ were obtained from the slope and the intercept, respectively. The $\Delta G^{\mathrm{o}}$ of adduct formation was obtained according to Eq. (4) (Table 1).

$\Delta G^{\mathrm{o}}=\Delta H^{\mathrm{o}}-T \Delta S^{\mathrm{o}}$

The linear plots of $\ln K$ against $1 / T$ for $\left[\mathrm{Co}(\mathrm{cd} 4 \mathrm{OMesalMeen})\left(\mathrm{PBu}_{3}\right)\right] \mathrm{ClO}_{4} \cdot \mathrm{H}_{2} \mathrm{O}$ with aromatic amines are shown in Figure 3. The similar plots are obtained for other systems. 


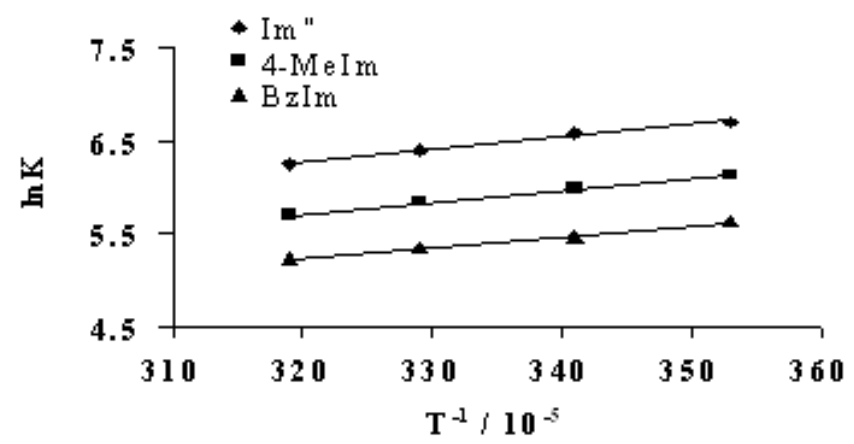

Figure 3. The plots of $\operatorname{lnK}$ vs. $1 / \mathrm{T}$ for $\left[\mathrm{Co}(\mathrm{cd} 4 \mathrm{OMesalMeen})\left(\mathrm{PBu}_{3}\right)\right] \mathrm{ClO}_{4} \cdot \mathrm{H}_{2} \mathrm{O}$ with $\mathrm{Im}$, 4-MeIm and BzIm at various temperatures in DMF.

Table 1. The formation constants, $10^{-2}(\mathrm{~K}) /\left(\mathrm{dm}^{3} \mathrm{~mol}^{-1}\right)$, and the thermodynamic parameter values, $\Delta \mathrm{H}^{\circ} /(\mathrm{kJ}$ $\left.\mathrm{mol}^{-1}\right), \quad \Delta \mathrm{S}^{\mathrm{o}} /\left(\mathrm{J} \quad \mathrm{K}^{-1} \mathrm{~mol}^{-1}\right), \quad \Delta \mathrm{G}^{\mathrm{o}} /\left(\mathrm{kJ}^{-1} \quad \mathrm{~mol}^{-1}\right)$ for $\left[\mathrm{Co}(\mathrm{cd} 5 \mathrm{OMesalMeen})\left(\mathrm{PBu}_{3}\right)\right] \mathrm{ClO}_{4} \cdot \mathrm{H}_{2} \mathrm{O}$, $\left[\mathrm{Co}(\mathrm{cd} 4 \mathrm{OMesalMeen})\left(\mathrm{PBu}_{3}\right)\right] \mathrm{ClO}_{4} \cdot \mathrm{H}_{2} \mathrm{O}$ and $\left[\mathrm{Co}(\mathrm{cd} 3 \mathrm{OMesalMeen})\left(\mathrm{PBu}_{3}\right)\right] \mathrm{ClO}_{4} \cdot \mathrm{H}_{2} \mathrm{O}$ with various cyclic amines in DMF at different temperature $(\mathrm{K})$.

\begin{tabular}{|l|c|c|c|c|c|c|c|c|c|}
\hline $\mathrm{T}(\mathrm{K})$ & \multicolumn{3}{|c|}{$\mathrm{Im}$} & \multicolumn{3}{c|}{ 4-MeIm } & \multicolumn{3}{c|}{ Bz-Im } \\
\hline & $4 \mathrm{OMe}$ & $3 \mathrm{OMe}$ & $5 \mathrm{OMe}$ & $4 \mathrm{OMe}$ & $3 \mathrm{OMe}$ & $5 \mathrm{OMe}$ & $4 \mathrm{OMe}$ & $3 \mathrm{OMe}$ & $5 \mathrm{OMe}$ \\
\hline 283 & 55.77 & 16.11 & 8.15 & 47.76 & 10.30 & 4.64 & 32.84 & 7.70 & 2.83 \\
& \pm 2.65 & \pm 0.14 & \pm 0.62 & \pm 2.51 & \pm 0.78 & \pm 0.38 & \pm 1.38 & \pm 0.22 & \pm 0.12 \\
\hline 293 & 42.33 & 13.22 & 7.23 & 37.91 & 8.20 & 3.98 & 25.80 & 6.30 & 2.38 \\
& \pm 1.44 & \pm 2.18 & \pm 0.85 & \pm 0.60 & \pm 0.23 & \pm 0.43 & \pm 1.32 & \pm 0.17 & \pm 0.16 \\
\hline 303 & 35.11 & 10.69 & 6.06 & 30.43 & 7.00 & 3.46 & 20.90 & 5.15 & 2.14 \\
& \pm 1.76 & \pm 1.10 & \pm 0.28 & \pm 028 & \pm 0.36 & \pm 0.17 & \pm 0.63 & \pm 0.27 & \pm 0.08 \\
\hline 313 & 27.36 & 8.80 & 5.24 & 23.98 & 5.70 & 2.99 & 17.12 & 4.40 & 1.90 \\
& \pm 0.89 & \pm 0.83 & \pm 0.13 & \pm 0.16 & \pm 0.42 & \pm 0.07 & \pm 0.31 & \pm 0.13 & \pm 0.03 \\
\hline$\Delta H^{\mathrm{o}}$ & -17.12 & -14.93 & -11.02 & -16.83 & -14.25 & -10.73 & -15.97 & -13.87 & -9.64 \\
& \pm 0.78 & \pm 0.33 & \pm 0.69 & \pm 0.46 & \pm 0.60 & \pm 0.18 & \pm 0.17 & \pm 0.32 & \pm 0.59 \\
\hline$\Delta S^{\mathrm{o}}$ & 11.17 & 8.72 & 16.92 & 11.02 & 7.29 & 13.16 & 10.87 & 6.24 & 12.77 \\
& \pm 2.63 & \pm 1.11 & \pm 2.33 & \pm 1.56 & \pm 2.03 & \pm 0.63 & \pm 0.58 & \pm 1.07 & \pm 1.98 \\
\hline$\Delta G^{\mathrm{o}}$ & -20.51 & -17.57 & -16.15 & -20.18 & -16.46 & -14.72 & -19.26 & -15.76 & -13.52 \\
& \pm 1.11 & \pm 0.47 & \pm 0.99 & \pm 0.66 & \pm 0.86 & \pm 0.27 & \pm 0.24 & \pm 0.45 & \pm 0.84 \\
\hline
\end{tabular}

The acceptor property of cobalt(III) Schiff base complexes

To study of the effects of the electronic properties of Schiff bases on the acceptor properties of $\left[\mathrm{Co}(\mathrm{cd} 3 \mathrm{OMesalMeen})\left(\mathrm{PBu}_{3}\right)\right] \mathrm{ClO}_{4} \cdot \mathrm{H}_{2} \mathrm{O}, \quad\left[\mathrm{Co}(\mathrm{cd} 4 \mathrm{OMesalMeen})\left(\mathrm{PBu}_{3}\right)\right] \mathrm{ClO}_{4} \cdot \mathrm{H}_{2} \mathrm{O} \quad$ and $\left[\mathrm{Co}(\mathrm{cd} 5 \mathrm{OM}\right.$ esalMeen $\left.)\left(\mathrm{PBu}_{3}\right)\right] \mathrm{ClO}_{4} \cdot \mathrm{H}_{2} \mathrm{O}$ complexes, the thermodynamic study of these complexes with amines as donors in ethanol $95 \%$ were carried out. The trend of formation constants of the studied complexes is in the following sequence: [Co(cd4OMesalMeen $\left.)\left(\mathrm{PBu}_{3}\right)\right]^{+}$ $>\left[\mathrm{Co}(\mathrm{cd} 3 \mathrm{OM} \text { esalMeen })\left(\mathrm{PBu}_{3}\right)\right]^{+}>\left[\mathrm{Co}(\mathrm{cd} 5 \mathrm{OM} \text { esalMeen })\left(\mathrm{PBu}_{3}\right)\right]^{+}$.

This is according to the electronic spectra that the charge donation from $\mathrm{Co}$ (III) ion to Schiff base's $\pi^{*}$ molecular orbital is decreased by electron releasing methoxy groups on the Schiff bases ligands. The methoxy functional group is a donating group and stabilizes the fivecoordinated complexes. In the case of $\left[\mathrm{Co}(\mathrm{cd} 5 \mathrm{OM} e s a l M e e n)\left(\mathrm{PBu}_{3}\right)\right]^{+}$complex, the methoxy group is situated in the para position to the phenolic oxygen donor atoms of NNOS backbone, can release the electron directly [40] and its complex has the lowest formation constants toward amines than $4 \mathrm{OMe}$ and $3 \mathrm{OMe}$ groups. 3OMe group is near to core complex and is better donor 
electron than that of meta position in the $\left[\mathrm{Co}(\mathrm{cd} 4 \mathrm{OMesalMeen})\left(\mathrm{PBu}_{3}\right)\right]^{+}$complex. Therefore, the $\left[\mathrm{Co}(\mathrm{cd} 3 \mathrm{OMesalMeen})\left(\mathrm{PBu}_{3}\right)\right]^{+}$has the smallest formation constants (see Table 1).

\section{The effect of the cyclic amine donors}

The investigation of the metal binding properties of imidazol and their derivative based ligands, owing to the extremely broad biological presence of imidazol moiety, is one of the main topics of biocoordination chemistry. Following our earlier studies on the coordination behavior, here we report the formation constants for three Co(III) Schiff base complexes with three cyclic amine donors Im, 4-MeIm and BzIm. The electron donating groups in the base increase the tendency of the organic bases toward the small acids like $\mathrm{H}^{+}$. On the other hand, the binding tendency of the organic bases toward the Co(III) centre is almost compatible with their steric rather than their basicity character when the size of acids was increased [41]. The basic constants, $\mathrm{K}_{\mathrm{b}}$, of the donor amines applied in this study are increased according to the trend: $\mathrm{Im}$, 4-MeIm, BzIm have the $\mathrm{pK}_{\mathrm{a}}=6.73,6.92,7.96$ [42], the formation constants for these bases with $\left[\mathrm{Co}(\mathrm{cd} 3 \mathrm{OMesalMeen})\left(\mathrm{PBu}_{3}\right)\right]^{+}, \quad\left[\mathrm{Co}(\mathrm{cd} 4 \mathrm{OMesalMeen})\left(\mathrm{PBu}_{3}\right)\right]^{+}$and $\left[\mathrm{Co}(\mathrm{cd} 5 \mathrm{OMesalMeen})\left(\mathrm{PBu}_{3}\right)\right]^{+}$complexes are decreased with increasing steric hindrance of the donor bases (Table 1):

$$
\operatorname{Im}>\text { 4-MeIm > BzIm }
$$

\section{The effect of the linear aliphatic amine donors}

Cobalt (III) Schiff base complexes with amines as five and six coordinated axial ligands have been shown to inhibit the replication of the ocular hepes virus. Their well known that these complexes have a high affinity for nitrogenous donors such as histidine residues, and it is possible that they bind to an enzyme that is crucial to viral replication [43]. In continuation of our studies on formation constants of cobalt (III) complexes as acceptor, three aliphatic amines ( $n$-butylamine, sec-butylamine and tert-buthylamine) have been examined as donors.

The aliphatic amines have important electronic and steric properties. The steric factor is shown by Trogler's cone angle [44]. The steric effect is increased with an increase in the cone angle, and formation constants were decreased by increasing cone angles (Table 2). The formation constants for the given complexes increasing according to the following trend of amines: $n$-butylamine $>$ sec-butylamine $>$ tert-buthylamine.

The base strengths (electronic factor) of non-aromatic amines were plotted against the Taft $\sigma^{*}$-values [45]. On the basis of the electronic effect, the formations constant are in the following sequences (Table 2): $n$-butylamine $>$ sec-butylamine $>$ tert-buthylamine.

Therefore, the trend of reactivity of amines toward a given substrate that is affected by both the electronic and steric factors is as follow: $n$-butylamine $>\sec$-butylamine $>$ tert-buthylamine.

Table 2. The formation constants, $10^{-2}(\mathrm{~K}) /\left(\mathrm{dm}^{3}\right.$. $\left.\mathrm{mol}^{-1}\right)$, for $\left[\mathrm{Co}(\mathrm{cd} 3-, 4-\right.$, 5-OMesalMeen $\left.)-\left(\mathrm{PBu}_{3}\right)\right] \mathrm{ClO}_{4} \cdot \mathrm{H}_{2} \mathrm{O}$ with various aliphatic amines in DMF.

\begin{tabular}{|l|c|c|c|c|c|}
\hline Amine & Cone angle & $\sigma^{*}$ & 4OMe & 3OMe & $5 \mathrm{OMe}$ \\
\hline$n$-butylamine & - & +0.85 & $10.84 \pm 0.96$ & $8.64 \pm 0.21$ & $6.64 \pm 0.26$ \\
\hline sec-butylamine & 113 & +0.77 & $6.54 \pm 0.43$ & $5.63 \pm 0.32$ & $3.12 \pm 0.13$ \\
\hline tert-butylamine & 123 & +0.68 & $5.71 \pm 0.16$ & $4.12 \pm 0.04$ & $2.11 \pm 0.06$ \\
\hline
\end{tabular}

The effect of the solvents

The formation constants and the free energies were determined in acetonitrile, dimethylformamide and ethanol for $\left[\mathrm{Co}(\mathrm{cd} 4 \mathrm{OMesalMeen})\left(\mathrm{PBu}_{3}\right)\right] \mathrm{ClO}_{4} \cdot \mathrm{H}_{2} \mathrm{O}$ complex with sec- 
butylamine in $293 \mathrm{~K}$ (Table 3). According to the literature if in the six-coordinated complexes a solvent molecule occupies the sixth position; the interaction with the donor base is very weak. Therefore it seems that, for this type of five-coordinated complexes, there is a tendency for the interaction with a solvent molecule to form six-coordinate complex according to the following Eq. (5):

$\left[\mathrm{Co}(\mathrm{Chel})\left(\mathrm{PBu}_{3}\right)\right]^{+}+\mathrm{S} \leftrightarrow\left[\mathrm{Co}(\mathrm{Chel})\left(\mathrm{PBu}_{3}\right) \mathrm{S}\right]^{+}$

where $\mathrm{S}=$ solvent molecule. The results show that the formation constants are dependent upon on the solvent. These effects are related to many factors, one of them is Gutmann donor number. The Gutmann donor number for $\mathrm{EtOH}$ is 32, for DMF is 26.6 and 14.1 for $\mathrm{CH}_{3} \mathrm{CN}$ [31]. The trend of influence of the solvent on the reactivity of the studied complex toward sec-butylamine is: $\mathrm{CH}_{3} \mathrm{CN}>\mathrm{DMF}>\mathrm{MeOH}$.

The formation constants in ethanol with higher donor number are smaller than acetonitrile and dimethylformamide. Therefore the formation constant decreases with increasing the donor number of the solvent. This result confirms that the five-coordinated complex is more stable in solvent with higher donor number (Eq. 5). In other words, a solvent with high donor number can coordinate to a five-coordinated complex and stabilizes it toward a higher coordination number.

Table 3. The formation constants, $10^{-2}(\mathrm{~K}) /\left(\mathrm{dm}^{3}\right.$. $\left.\mathrm{mol}^{-1}\right)$, and the thermodynamic parameter values, $\Delta \mathrm{H}^{\circ} /(\mathrm{kJ}$ $\left.\mathrm{mol}^{-1}\right), \Delta \mathrm{S}^{\mathrm{o}} /\left(\mathrm{J} \mathrm{K}^{-1} \mathrm{~mol}^{-1}\right), \Delta \mathrm{G}^{\mathrm{o}} /\left(\mathrm{kJ} \mathrm{mol}^{-1}\right)$ for $\left[\mathrm{Co}(\mathrm{cd} 4 \mathrm{OMesalMeen})\left(\mathrm{PBu}_{3}\right)\right] \mathrm{ClO}_{4} \cdot \mathrm{H}_{2} \mathrm{O}$ with $\mathrm{Im}$ in different solvents at different temperature $(\mathrm{K})$.

\begin{tabular}{|l|c|c|c|}
\hline $\mathrm{T}(\mathrm{K})$ & $\mathrm{CH}_{3} \mathrm{CN}$ & $\mathrm{DMF}$ & EtOH \\
\hline 283 & $43.16 \pm 3.22$ & $16.11 \pm 0.14$ & $15.80 \pm 1.06$ \\
\hline 293 & $26.05 \pm 1.66$ & $13.22 \pm 2.18$ & $11.50 \pm 0.53$ \\
\hline 303 & $16.60 \pm 1.28$ & $10.69 \pm 1.10$ & $10.03 \pm 0.53$ \\
\hline 313 & $11.00 \pm 0.85$ & $8.80 \pm 0.83$ & $7.50 \pm 0.14$ \\
\hline$\Delta \mathrm{H}^{\mathrm{o}}$ & $-33.58 \pm 0.38$ & $-14.93 \pm 0.33$ & $-11.28 \pm 0.63$ \\
\hline$\Delta \mathrm{S}^{\text {o }}$ & $49.07 \pm 1.28$ & $8.72 \pm 1.11$ & $-6.82 \pm 2.13$ \\
\hline$\Delta \mathrm{G}^{\text {oa }}$ & $-18.70 \pm 0.54$ & $-17.57 \pm 0.47$ & $-17.39 \pm 0.90$ \\
\hline
\end{tabular}

Thermodynamic parameters

The equilibrium constants were carried out at various temperatures by increasing the temperature, the formation constants were decreased. In general, the $\Delta \mathrm{H}^{\mathrm{o}}$ value and its sign are dependent on the salvation effect and the heat of formation of the complex [47]. In all cases (Tables 1,3 ), the enthalpy values are negative because of bond formation in all reactions. This shows that the complex formation contribution of $\Delta \mathrm{H}^{\mathrm{o}}$ values is more important. The enthalpy changes of amines toward these complexes are related to the equilibrium constants for these systems and with enhancing the tendency of adduct formation, the enthalpy changes become more negative (Table 1). On the other hand, the $\mathrm{Co}(\mathrm{III})$ complexes in acetonitrile is more negative than for other solvents which shows that the complex formation for these complexes in this solvent $\left(\mathrm{CH}_{3} \mathrm{CN}\right)$ is more important (Table 3).

The value of the $\Delta S^{o}$ and its sign are dependent on the difference in the number of the particles of the initial substances and the product complexes, and the liberation of the solvent molecules from the salvation shells [47]. $\Delta \mathrm{n}$ for the reactions involving [Co(cd3-, 4-, 5OMesalMeen $\left.)\left(\mathrm{PBu}_{3}\right)\right]^{+}$with amine is -1 and the entropy changes is decreased. According to the second factor, the effects $\Delta \mathrm{S}^{\mathrm{o}}$ predominantly and its sign is positive. Comparing the two factors, it is the second one that determines the sign of the outcome $\Delta \mathrm{S}^{\circ}$ during the adduct formation. 


\section{Antimicrobial activity}

The Schiff base ligands and its metal complexes were evaluated for standardized disk-agar diffusion method [48] was followed to determine the activity of the synthesized compound against Gram positive bacteria (Staphylococcus aureus) and Gram negative bacteria (Escherichia coli). Tetracycline was used as standard references in the case of bacteria. The tested compounds were dissolved in dimethylsulfuxide (DMSO) to get concentration of 2 $\mathrm{mg} / \mathrm{mL}$. In order to clarify any effect of solvent DMSO on the biological screening, separate studies were carried out with solvent DMSO only and it's showed no activity against any microbial strains. The sensitivity of a microorganism to antibiotics was determined by assay plates which were incubated at $37^{\circ} \mathrm{C}$ for one day for bacteria. The data are listed in Table 4 . The Schiff base ligands were found to be biologically active and its cobalt complexes showed some antibacterial activity. The remarkable result is that the complexes showed lower inhibition against $E$. coli and $S$. aureus as compared with its ligand. This can be explained as follows: the biological activity of the Schiff base ligand is related to the imine moiety, which plays a key role in the inhibition of the tested bacteria. The lower antimicrobial activity of the cobalt complexes compared with that in the ligand may be due to the strong interaction between the imine moieties and the cobalt ions, such interaction will reduce the activity of the imine moiety in the inhibition. The importance of this unique property of the investigated Schiff base complexes lies in the fact that, it could be applied in the treatment of infections caused by any of these particular strais.

Table 4. Antibacterial activity of the Schiff base ligands and their Co(III) complexes (mg/mL).

\begin{tabular}{|l|c|c|}
\hline Sample & Escherichia coli & Staphylococcus aureus \\
\hline $\mathrm{H}_{2}$ cd3OMesalMeen & 25 & 25 \\
\hline $\mathrm{H}_{2}$ cd4OMesalMeen & 23 & 27 \\
\hline $\mathrm{H}_{2}$ cd5OMesalMeen & 20 & 21 \\
\hline$\left[\mathrm{Co}(\text { cd3OMesalMeen })\left(\mathrm{PBu}_{3}\right)\right]^{+}$ & 19 & 19 \\
\hline$\left[\text { Co }(\text { cd4OMesalMeen })\left(\mathrm{PBu}_{3}\right)\right]^{+}$ & 19 & 20 \\
\hline$[$ Co(cd5OMesalMeen $\left.)\left(\mathrm{PBu}_{3}\right)\right]^{+}$ & 16 & 18 \\
\hline tetracycline & 32 & 34 \\
\hline
\end{tabular}

\section{CONCLUSION}

In this paper, we have explored the synthesis and coordination chemistry of cobalt complexes derived from the Schiff base ligands $\left[\mathrm{H}_{2} \mathrm{~cd} 3,4,5-\mathrm{OMesalMeen}\right]$. Biological activity revealed that the ligands have higher antimicrobial activity compared to the cobalt complexes. By considering the formation constants, $K_{\mathrm{f}}$, free energies, $\Delta \mathrm{G}^{\mathrm{o}}$, and enthalpy, $\Delta \mathrm{H}^{\mathrm{o}}$, of formation for the fivecoordinate cobalt(III) unsymmetrical Schiff base complexes as acceptors and amines as donors, the following conclusion have been drawn: (i) The formation constants trend of the acceptor properties of the cobalt(III) unsymmetrical Schiff base complexes toward a given amine is as: $\left[\mathrm{Co}(\mathrm{cd} 4 \mathrm{OMesalMeen})\left(\mathrm{PBu}_{3}\right)\right]^{+}>\left[\mathrm{Co}(\mathrm{cd} 3 \mathrm{OMesalMeen})\left(\mathrm{PBu}_{3}\right)\right]^{+}>\left[\mathrm{Co}(\mathrm{cd} 5 \mathrm{OMesalMeen})\left(\mathrm{PBu}_{3}\right)\right]^{+}$. (ii) The formation constants for a given acceptor changes are according to the following trend for donors due to the steric and the electronic factors: $n$-butylamine $>$ sec-butylamine $>$ tertbuthylamine $>\operatorname{Im}>4$-MeIm $>$ BzIm. (iii) The formation constants for a given donor and acceptor changes are according to the following trend for different solvents due to the donor number: $\mathrm{CH}_{3} \mathrm{CN}>\mathrm{DMF}>\mathrm{MeOH}$. (iv) The reactions are exothermic, i.e. by increasing the temperature, the formation constant is decreased. $\Delta H^{\mathrm{o}}<0$. 


\section{ACKNOWLEDGEMENTS}

We are grateful to Islamic Azad University, Darab Branch Research Council for their financial support. The authors express their sincere thanks to Dr. Banafsheh Esmaielzadeh, Department of Anatomy, Bushehr University of Medical Science, Bushehr 5714633196, Iran, for providing biological data preparation.

\section{REFERENCES}

1. Pattanayak, P.; Pratihar, L.; Patra, D.; Brandao, P.; Mal, D.; Felix, V. Polyhedron, 2013, 59, 23.

2. Alhadi, A.A.; Shaker, Sh.A.; Yehye, W.A.; Mohd Al, H.; Abdullah, M.A. Bull. Chem. Soc. Ethiop. 2012, 26, 95.

3. Alias, M.; Kassum, H.; Shakir, C. J. Asso. Arab. Univ. Bas. App. Sci. 2014, 15, 28.

4. Hu, X.M.; Xue, L.W.; Zhao, G.Q.; Yang, W.C. Bull. Chem. Soc. Ethiop. 2015, 29, 407.

5. Bhowmik, P.; Chattopadhyay, Sh.; Drew, M.G.B. Inorg. Chim. Acta 2013, 395, 24.

6. Rodrigues, L.; Labisbal, E.; Sousa-pedrares, A.; Garcia-vazquez, J.A.; Romero, J.; Sousa, A. Inorg. Chim. Acta 2010, 363, 1284.

7. Jana, S.; Bhowmik, P.; Das, M.; Jana, P.P.; Harms, K.; Chattopadhyay, Sh. Polyhedron 2012, 37, 21.

8. Mandal, S.; Modak, R.; Goswami, S. J. Mol. Struct. 2013, 1037, 352.

9. Chandra, S.; Bargujar, S.; Nirwal, R.; Yadav, N. Spectrochim. Acta, Part A. Mol. Biomol. Spect. 2013, 106, 91.

10. Yaul, A.R.; Dhande, V.V.; Pethe, G.B.; Aswar, A.S. Bull. Chem. Soc. Ethiop. 2014, 28, 255.

11. Amirnasr, M.; Rasouli, M.; Mereiter, K. Inorg. Chim. Acta 2013, 404, 230.

12. Chakraborty, A.; Kumar, P.; Ghosh, K.; Roy, P. Eur. J. Pharma. 2010, 647, 1.

13. El-Sherif, A.A.; Eldebss, T.M.A. Spectrochim. Acta, Part A. Mol. Biomol. Spect. 2011, 79, 1803.

14. Dai, C.H.; Mao, F.L. J. Struc. Chem. 2013, 54, 624.

15. Pradeepa, S.M.; Bhojya, N.; Kumar, V.B.; Priyadarsini, I.; Barik, A.; Ravikumar, N. Spectrochim. Acta, Part A. Mol. Biomol. Spect. 2013, 101, 132.

16. Li, J.N. Synth. Reac. Inorg. Met-Org. Nano-Met. Chem. 2013, 43, 826.

17. Sathisha, M.P.; Shetti, U.N.; Revankar, V.K.; Pai, K.S.R. Eur. J. Med. Chem. 2008, 43, 2338.

18. Sakthialatha, D.; Rajavel, R. J. Chem. Pharma. Res. 2013, 5, 57.

19. Esmaielzadeh, Sh.; Azimian, L.; Shekoohi, Kh.; Esfandiari, H.; Asadi, M.; Zare, Z.; Rahmani nejad, A.; Mohammadi, Kh. Inorg. Chim. Acta 2013, 405, 155.

20. Asadi, M.; Mohammadi, Kh.; Esmaielzadeh, Sh.; Etemadi, B.; Kun Fun, H. Polyhedron 2009, 28, 1409 .

21. Asadi, M.; Mohammadi, Kh.; Esmaielzadeh, Sh.; Etemadi, B.; Kun Fun, H. Inorg. Chim. Acta 2009, 362, 4913.

22. Asadi, M.; Esmaielzadeh, Sh.; Mohammadi, Kh. Acta Chim. Slov. 2009, 56, 927.

23. Asadi, M.; Esmaielzadeh, Sh.; Mohammadi, Kh. Phosphorous, Sulfur, Silicon, Rela. 2010, $185,1445$.

24. Nag, K.; Joardar, D.S. Inorg. Chim. Acta 1975, 14, 133.

25. Bordas, B.; Sohar, P.; Matolcsy, G.; Berencsi, P. J. Org. Chem. 1972, 37, 1727.

26. Pereira, E.; Gomes, L.; De-Castro, B. Inorg. Chim. Acta 1998, 271, 83.

27. Indira Devi, G.; Saba, P.G.; Geetha, P. Res. J. Chem. Sci. 2013, 3, 58.

28. Pria Devi, T.; Hemakumar Singh, R.K. Rasayan. J. Chem. 2010, 3, 266.

29. Karabocek, N.; Karabocek, S.; Kormali, F. Turk. J. Chem. 2007, 31, 271.

30. Daneshvar, N.; Entezami, A.A.; Khandar, A.A.; Saghatforosh, L.A. Polyhedron, 2003, 22, 1437. 
31. Hamid, M.H.S.A.; Akbar Ali, M.; Mirza, A.H.; Bernhardt, P.V.; Moubaraki, B.; Murray, K.S. Inorg. Chim. Acta 2009, 362, 3648.

32. Singh, K.; Kumar, Y.; Puri, P.; Sharma, Ch. Eur. J. Med. Chem. 2012, 52, 313.

33. Asadi, M.; Setoodehkhah, M.; Kianfar, A.H. J. Iran. Chem. Soc. 2010, 7, 38.

34. Mohammed, L.A.; Kahim, A.J.; Aubaid, N.H. Acta Chim. Pharma. Indica 2013, 3, 111.

35. Emara, A.A. Spectrochim. Acta, Part A. Mol. Biomol. Spect. 2010, 77, 117.

36. Akbar Ali, M.; Mirza, A.H.; Bakar, H.J.H.A.; Bernhardt, P.V. Polyhedron 2011, 30, 556.

37. Dede, B.; Karpcin, F.; Cengiz, M. J. Hazard. Mater. 2009, 163, 1148.

38. Ahmed, R.M.; Yousif, E.I.; Al-Jeboori, M.J. Sci. World J. 2013, 2013, 1.

39. Ketelaar, J.A.A.; Van De Stolpe, C.; Coulsit, A.; Dz Cubes, W. Rec. Trav. Chim. 1952, 71, 1104.

40. Asadi, M.; Aein Jamshid, Kh.; Kianfar, A.H. Inorg. Chim. Acta 2007, 360, 1725.

41. Miessler, G.L; Tarr, D.A. Inorganic Chemistry, Prentice-Hall: New Jersey; 1991.

42. Hofman, K. The Chemistry of Hetrocyclic Compounds, Imidazole and Its Derivatives, Part I, Interscience Publisher Inc.: New York; 1953.

43. Bottcher, A.; Takeuchi, T.; Quezada, C.M.; Meade, T.J.; Gray, H.B. Bioinorg. Med. Chem. 1999, 7, 815.

44. Trogler, W.C.; Seligson, A.L. J. Am. Chem. Soc. 1991, 113, 2520.

45. Hall, H.K. J. Am. Chem. Soc. 1957, 79, 5441.

46. Marcus, Y. The Properties of Solvent, John Wiley and Sons: New York; 1999.

47. Abrland, S. Helv. Chim. Acta 1967, 50, 306.

48. Bauer, A.W.; Kirby, W.W.M.; Sherris, J.C.; Turck, M. Am. J. Clin. Pathol. 1966, 45, 493. 